\title{
A Christmas Carol - or how I learned to love visits from the dead
}

cambridge.org/pax

\section{Essay/Personal Reflection}

*The author was formerly 50th Anniversary Professor (End-of-Life Care) at the University of Bradford, UK.

Cite this article: Kellehear A (2023). A Christmas Carol - or how I learned to love visits from the dead. Palliative and Supportive Care 21, 169-170. https://doi.org/10.1017/ S1478951521001231

Received: 11 June 2021

Revised: 6 July 2021

Accepted: 11 July 2021

Author for correspondence:

Allan Kellehear,

College of Nursing and Health Sciences, University of Vermont, Burlington, VT, USA. E-mail: a.kellehear@bradford.ac.uk
Allan Kellehear, PH.D., FAC.S.S.* (D)

College of Nursing and Health Sciences, University of Vermont, Burlington, VT

Marley was dead: to begin with.

So opens Charles Dickens' festive ghost story "A Christmas Carol" (Dickens, 1922). There are many reasons that this tale about a ghostly visit to Ebenezer Scrooge by his dead friend Marley remains ever popular for repeated film adaptations. For one thing, it's a story that evokes personal reflection about one's life as each year draws to a close, metaphorically suggesting the close of a life. For another thing, it's a very funny story about visiting specters, for an audience and a time when religious ideas about the afterlife were rapidly receding. But I think an overlooked reason for the popularity of Scrooge can also be found in the surprising number of people who can personally relate to the occurrence of a visit from their dead. A lot of people, sometimes shockingly, and often counter to expectation and their own reason, get visits from their dead. They line up at your front door like Avon Ladies, Mormons, or purveyors of time-share.

My first brush with a Marley-like experience came in the 1960s when I was 12 years old. I was taking piano lessons from Miss Marcus, a middle-aged Dutch woman. Unmarried, she lived with her elderly 80 something mother. While practicing my scales under the watchful eye of Miss Marcus I would often see her mother from the corners of my eyes, as she drifted slowly about the house. Early indications of my own lack of concentration I confess, and lack of promise at the keyboard.

One day, I received the happy news that piano lessons were canceled for a month. When I returned to my lessons, I learned from Miss Marcus that her mother had suddenly taken ill and was hospitalized. She died some days later. I was very sad to hear that news and offered my condolences, such as they were from a 12 year old. Among my awkward attempts to comfort, I suggested that maybe her mother was now in Heaven. In my mind, this was not a religious place but merely a happy place somewhere near, somehow hidden from human view. A place where I thought my dead dogs might be, and for reasons I still can't explain, where some of my missing bottle cap collection might have ended up.

Miss Marcus dismissed the idea. "Heaven" or the "afterlife" was a story for children and superstitious people she declared, a judgment made somehow more final when delivered in a Dutch-accent. We said no more about it. Some months later, after another sadly underperforming practice session from me, Miss Marcus kept me back to share a personal story about a recent event.

One afternoon, with no lessons scheduled, Miss Marcus went into her kitchen to collect an orange, a small plate, and a peeling knife. She returned to her lounge room to find a comfortable chair when suddenly, her dead mother appeared in relaxed pose on their couch. Mrs. Marcus looked very well indeed, even somewhat younger. She was dressed in a favorite dress she had been buried in. She looked directly at her daughter and smiled warmly, and then was gone, almost as suddenly as she appeared. Curiously, Miss Marcus recounted the story with a rather flat affect, without emotion. I, on the other hand, managed to school my features consistent with the seriousness of the occasion. Internally however, I was really feeling that I had witnessed the landing of a flying saucer, in broad daylight, in my own front garden! I was thrilled to pieces.

Surely, Miss Marcus must now believe in the afterlife. But like Scrooge when he first encountered the rather theatrical Marley in all his post-death regalia, Miss Marcus was unsure. She doubted her senses in spite of their apparent clarity, as Scrooge first observed, because any "little thing affects them." What initially appears to be the dead may in truth be, "an undigested bit of beef, a blot of mustard, a crumb of cheese, a fragment of underdone potato." So too, a mid-afternoon orange might bring on a delusion or unwanted vision. But herein lies the rub. She hadn't eaten the orange, and the visit was not unwelcome. If like John Lennon we accept there's no heaven, no religion too, and no hallucinatory effects from orange fumes, what lingered with Miss Marcus after the impersonal theories about the returning dead had exhausted themselves?

It turns out the visit left a legacy of hope, personal meaning, the sense of a love returned, and a certain emotional humility. The Dutch certainty left her from that day forward - at least in the firmness of her position on the great public debates between religion and science. Formerly a poster child for a materialist view of the world, she now saw past the rival ideologies 
of who was right or wrong, and instead embraced what appeared to be a personal gift to her from her mother. I could see that she was glad, even grateful to see her mother again. I could hear the hope in her voice that her new uncertainty gave her. She had found a new personal meaning inside the life, evidently the continuing life, of her dear and much loved mother. This reshaping of her inner life based on this unexpected but powerful experience did not cancel her prior beliefs so much as eclipsing them. The gift to her was a new openness.

This transformation would appear idiosyncratic if it were not for the fact that the event, experience, and interpretation are widely prevalent in all societies, including our own recent one. Some $10-20 \%$ of people who have near-death experiences see and hear their dead (Van Lommel, 2004; Holden et al., 2009). They report beings and places of light, but they also commonly report meeting deceased family and friends, even former animal companions, in their time before being resuscitated. Some 30\% of people on their deathbed report visions of deceased family or friends coming to visit them at their bedside (Kellehear, 2020). Sometimes, the dying report visits from the dead even while the living visitors are still present. And self-reports of dead visitors from the world's bereaved have a prevalence range from 30 to $80 \%$ (Kellehear, 2017), the higher figure from societies like Japan where visits from the dead are culturally expected and encouraged (Laroi et al., 2014).

These experiences are old and they are cross-cultural (Frazer, 1911-14; Zaleski, 1987; Shushan, 2009). The world's bank of ethnographic and folkloric literature regularly describes these events and experiences (Malinowski, 1948). These stories litter the oral traditions of indigenous peoples in Australia or Asia, peasant farming communities from Africa or Europe, and in our modern cities fresh from the last ice age, from Ancient Athens or Victorian London, to 21st century New York or Tokyo. Moreover, it is not only the same story they tell, but also the same outcomes and transformations I witnessed in Miss Marcus.

But in recent times, we have forgotten this literature and these lessons, reducing folklore to tall tales for children or the superstitious. We look to our new or older friends - the science of our times or the religions of old. With these friends in tow, we are able to deploy a stop-and-go system for our anxieties and the unexpected. We rebuild new religious images from the spare parts of the old ones, or use scientific optimism as a wrecking ball to reduce mysteries to hypotheses. Visits from the dead? They just have to be a "Hello from Heaven" (Guggenheim and Guggenheim, 1996), as one bestselling book describes them. If not, then they just have to be a "good-bye to sanity" as some of the neuroscience literature will have you believe (Mobbs and Watt, 2011). If there are no witnesses, we are in the territory of memories, dreams, and hallucinations. Either way, both sides seem to speak with that old familiar Teutonic accent again.

But when we look closer at the first person accounts of visits from the dead from colonial America to Victorian England, from recent hospital wards, hospices, or bereavement counseling rooms across the world, no one seems to really care about the cause. This is because away from the academic conjecture and posturing, the only truth that manages to escape is that no one really knows why the dead visit - with one important exception - the person visited.

When we ask these people about the visits they have had from their dead, we are reminded of the lessons, themes, and principles passed down to us from the anthropological and folkloric insights of old: the unexpected greeting and gift, the continuation of help and advice, the aftermath of transformation, a wondrous sense of vigil over our lives (Kellehear, 2020). No signs of cerebral anomaly or religious revival, visits from the dead are evidence of the persistence of hope and love in the valley of the shadow of death. Scrooge's final comment addressed to the last specter in his story, the ghost of Christmas-to-come, says it best: those who are lucky enough to see their dead again will "not shut out the lessons that they teach." I only wish one of them would return my missing bottle caps.

Funding. This research received no specific grant from any funding agency, commercial, or not-for-profit sectors.

Conflict of interest. There are no conflicts of interest.

\section{References}

Dickens C (1922) A Christmas Carol in Prose: Being a Ghost Story of Christmas. London: Cecil Palmer.

Frazer J (1911-14) The Belief in Immortality and the Worship of the Dead: 3 Volumes. London: Macmillan.

Guggenheim B and Guggenheim J (1996) Hello from Heaven. New York: Bantam.

Holden J, Greyson B and James D (eds) (2009) A Handbook of Near-Death Experiences: Thirty Years of Investigation. Santa Barbara, CA: ABC-CLIO.

Kellehear A (2017) Unusual perceptions at the end of life: Limitations to the diagnosis of hallucinations in palliative medicine. BMJ Supportive and Palliative Care 7(3), 238-246.

Kellehear A (2020) Visitors at the End of Life: Finding Meaning and Purpose in Near-Death Phenomena. New York: Columbia University Press.

Laroi F, Luhrmann TM, Bell V, et al. (2014) Culture and hallucinations: Overview and future directions. Schizophrenia Bulletin 40(Suppl 4), S213-S220.

Malinowski B (1948) Magic, Science and Religion. New York: Free Press.

Mobbs D and Watt C (2011) There is nothing paranormal about near-death experiences: How neuroscience can explain seeing bright lights, meeting the dead, or being convinced you are one of them. Trends in Cognitive Science $15,447-449$.

Shushan G (2009) Conceptions of the Afterlife in Early Civilizations. London: Continuum.

Van Lommel P (2004) About the continuity of consciousness. Advances in Experimental Medicine and Biology 550, 115-132.

Zaleski C (1987) Otherworld Journeys: Accounts of Near-Death Experiences in Medieval and Modern Times. New York: Oxford University Press. 